\title{
PERTUMBUHAN DAN PRODUKSI TANAMAN KENIKIR (Cosmos caudatus Kunth.) PADA BERBAGAI TINGKAT NAUNGAN
}

\author{
Growth and Production of Kenikir (Cosmos caudatus Kunth.) \\ at Various Levels of Shading
}

Revianto $^{1}$, Arifah Rahayu², Yanyan Mulyaningsih ${ }^{2}$

\begin{abstract}
ABSTRAK
Penelitian ini bertujuan untuk mengetahui pengaruh naungan (paranet) terhadap pertumbuhan dan produksi tanaman sayuran daun kenikir. Penelitian dilaksanakan pada bulan April sampai dengan September 2016 di Kebun Percobaan Agroteknologi Universitas Djuanda Bogor. Penelitian ini dilakukan dengan menggunakan rancangan petak terbagi. Sebagai petak utama adalah tingkat naungan, yaitu $0 \%$ (tanpa naungan), 25\%, 50\%, dan 75\%. Anak petak dalam penelitian ini adalah daerah asal bibit yaitu Bogor, Cianjur, danSukabumi. Penyusunan petak utama dan anak petak menggunakan rancangan acak lengkap. Hasil penelitian menunjukkan bahwa pemberian naungan $50 \%$ dan $75 \%$ pada 8 MST nyata menurunkan tinggi tanaman, panjang daun, diameter batang, bobot basah dan kering panen, tetapi meningkatkan lebar daun kenikir. Jumlah daun kenikir asal Sukabumi dan Cianjur lebih banyak dibandingkan dengan asal Bogor, kandungan klorofil daun kenikir asal Cianjur lebih banyak dibandingkan dengan asal Sukabumi dan Bogor, tetapi hasil panen ketiga aksesi tidak berbeda nyata.

Kata kunci : kandungan klorofil, rancangan petak terbagi, asal bibit, hasil panen
\end{abstract}

\begin{abstract}
This study was aimed at assessing the effects of shade (paranet) on the growth and production of kenikir (Cosmos caudatus). The study was conducted from April to September 2016 at the Agrotechnology Trial Farm of Djuanda University, Bogor. A split plot completely randomized design was used with shade levels, namely 0 (no shade), 25, 50, and 75\% as the main plot and places of origin, namely Bogor, Cianjur, and Sukabumi as the sub plot. Results showed that 50 and $75 \%$ shades at 8 weeks after planting (WAP) significantly decreased plant height, leave length, stem diameter, harvest fresh weight and harvest dry weight. Leaf width of kenikir was found to be higher. Number of leaves of kenikir of Sukabumi and Cianjur origins was higher than that of Bogor origin. Chlorophyl content of kenikir of Cianjur origin was higher than that of Sukabumi and Bogor origins. However, biomass yield harvested from all acessions was not different.
\end{abstract}

Key words: chlorophyl content, plant origin, harvest yield.

\section{PENDAHULUAN}

Indonesia memiliki keanekaragaman hayati tinggi, dan menempati posisi ketiga di dunia setelah Brazil dan Madagaskar (Baihaki 2003). Di Indonesia terdapat sekitar 100 jenis tanaman yang dapat dibudidayakan sebagai sayuran utama dan masih ada sekitar 50 jenis tanaman sayuran yang tumbuh liar (AVRDC 2008).
Selama ini budidaya dan konsumsi sayuran masih terfokus pada sayuran komersial, sementara sayuran indigenous masih terbatas pengembangannya. Vorster et al. (2007) menyatakan bahwa konsumsi sayuran indigenous yang masih rendah di tingkat rumah tangga disebabkan oleh (a) sayuran indigenous tidak selalu tersedia di pasar setiap saat, (b) kurangnya informasi mengenai diversifikasi produk yang berasal dari sayuran indigenous. 
Diantara sayuran indigenous yang potensial dikembangkan adalah kenikir. Tanaman ini termasuk kedalam famili Asteraceae, genus Cosmos, spesies Cosmos caudatus. Bagian tanaman kenikir yang sering digunakan adalah daun mudanya, antara lain untuk lalapan mentah atau dimasak, pelengkap pecel atau urap. Daun kenikir memiliki kandungan gizi yang baik. Dalam $100 \mathrm{~g}$ daun kenikir terdapat $93 \mathrm{~g}$ air, $3 \mathrm{~g}$ protein, $0.4 \mathrm{~g}$ lemak, $0.4 \mathrm{~g}$ karbohidrat, $1.6 \mathrm{~g}$ serat, $270 \mathrm{mg} \mathrm{Ca}$ dan $0.9 \mathrm{mg}$ vitamin A (Susila 2012). Selain itu daun kenikir memiliki khasiat, karena kandungan antioksidannya yang tinggi (Rafat et al. 2011). Menurut Lotulung et al., (2001), daya antioksidan daun kenikir memiliki harga IC50 sebesar $70 \mathrm{mg} / \mathrm{L}$. Secara tradisional daun kenikir digunakan sebagai obat penambah nafsu makan, lemah lambung, penguat tulang dan pengusir serangga (Setyaningrum dan Saparinto 2011).

Umumnya pengusahaan kenikir belum dilakukan secara intensif, tetapi masih dilakukan dalam skala kecil atau ditanam di pekarangan. Pengusahaan sayuran indigenous di pekarangan sering kali dihadapkan pada masalah naungan, sehingga perlu diketahui kemampuan tanaman tersebut untuk tumbuh dan berproduksi di bawah naungan.

Pengaruh naungan cenderung meningkatkan beberapa sifat, seperti masa dormansi, tinggi tanaman, diameter batang semu, panjang daun, lebar daun, jumlah daun, warna daun, jumlah anakan, jumlah stomata, kandungan klorofil daun, bobot basah dan bobot kering tajuk (Archita 2005). Oleh karena itu pada budidaya tanaman tertentu pembuatan naungan berfungsi untuk mengatur cahaya matahari secara langsung, menurunkan suhu tanah pada siang hari, memelihara kelembaban tanah dan mengurangi derasnya air hujan (Setyowati 2011). Penelitian ini bertujuan untuk mengetahui pengaruh tingkat naungan (paranet) terhadap pertumbuhan dan produksi tanaman sayuran kenikir.

\section{MATERI DAN METODE}

Penelitian ini dilaksanakan mulai bulan April 2016 - September 2016 di Kebun Percobaan Program Studi Agroteknologi
Universitas Djuanda Bogor. Analisis jumlah klorofil, dilakukan di Laboratorium Analisis Tanah Program Studi Agronomi dan Hortikultura IPB.

Alat yang digunakan meliputi paranet, alat pengolah tanah, polybag, gunting stek, embrat, penggaris, timbangan dan penyemprot pestisida. Bahan yang digunakan adalah biji tanaman kenikir, media tanam (tanah, arang sekam dan pupuk kandang) dengan perbandingan 1-1-1, pupuk urea, pupuk NPK (25-7-7).

Penelitian ini dilakukan dengan menggunakan rancangan petak terbagi. Sebagai petak utama adalah tingkat naungan, yaitu $0 \%$ (tanpa naungan), 25\%, 50\%, dan $75 \%$. Anak petak dalam penelitian ini adalah daerah asal bibit yaitu Bogor, Cianjur, dan Sukabumi.Penyusunan petak utama dan anak petak menggunakan rancangan acak lengkap.Dalam percobaan ini terdapat 12 kombinasi perlakuan dengan tiga ulangan, sehingga terdapat 36 satuan percobaan.Setiap satuan percobaan terdiri atas tiga tanaman.

Sebelum penanaman di lapang, dilakukan persemaian benih kenikir pada tray semai. Bibit dipindah-tanamkan ke kepolybag kecil pada umur 1 minggu setelah semai. Media tanam yang digunakan berupa campuran tanah, pupuk kandang, dan arang sekam dengan perbandingan 1:1:1. Media tanam dimasukan kedalam polybag berukuran $30 \times 40 \mathrm{~cm}$ dengan jarak tanam.

Lahan dibersihkan dari gulma dan dibuat naungan menggunakan paranet. Penanaman di lapang dilakukan pada waktu sore hari. Penyiraman dilakukan pada waktu pagi dan sore hari dengan memperhatikan faktor cuaca. Pengendalian gulma dilakukan secara manual. Pengamatan dilakukan seminggu sekali pada umur 2-8 minggu setelah tanam (MST).

Kegiatan panen dimulai pada 8, 9, dan 10 minggu setelah tanam (MST) berdasarkan tingkat kesiapan tanaman untuk dipanen. Panen selanjutnya dilakukan setiap minggu dengan cara memotong pucuk atau cabang yang masih muda sepanjang $20-30 \mathrm{~cm}$.

Pengamatan yang dilakukan meliputi pengamatan pertumbuhan dan produksi tanaman. Pengamatan pertumbuhan tanaman terdiri atas: tinggi tanaman, diameter batang, 
panjang daun, lebar daun, jumlah daun, bobot basah dan kering bagian yang dikonsumsi dan kandungan klorofil daun.

\section{HASIL DAN PEMBAHASAN}

\section{Keadaan Umun}

Pengumpulan bahan tanaman sayuran indigenous dilakukan di tiga kabupaten, yaitu Cianjur, Sukabumi dan Bogor. Penanaman bibit tanaman sayuran indigenous dilakukan di kebun percobaan Agroteknologi Universitas Djuanda. Penelitian ini dilakukan selama enam bulan. Selama penelitian berlangsung curah hujan rata-rata $306.33 \mathrm{~mm}$ per bulan (BMKG 2016-2017), suhu bekisar $24^{0} \mathrm{C}-30^{\circ} \mathrm{C}$ dengan kelembaban rata-rata sekitar $88 \%$.

\section{Hasil}

Tinggi tanaman kenikir dipengaruhi oleh naungan pada umur 5 - 8MST, tetapi tidak dipengaruhi daerah asal bibit. Pada umur 5 -8 $\quad$ MST tinggi tanaman kenikirpada perlakuan naungan $25 \%$ nyata lebih tinggi dibandingkan tingkat naungan lainnya, kecuali pada 8 MST tidak berbeda nyata dengan yang tidak dinaungi (Tabel 1).

Tabel 1 Tinggi tanaman kenikir umur 2-8 MST pada berbagai tingkat naungan dan asal daerah

\begin{tabular}{lccccccc}
\hline \multirow{2}{*}{ Perlakuan } & \multicolumn{7}{c}{ Tinggi tanaman $(\mathrm{cm})$} \\
\cline { 2 - 8 } & 2 MST & 3 MST & 4 MST & 5 MST & 6 MST & 7 MST & 8 MST \\
\hline Tingkat Naungan & & & & & & & \\
$0 \%$ & 6.52 & 10.40 & 12.79 & $17.87^{\mathrm{b}}$ & $24.59^{\mathrm{b}}$ & $58.00^{\mathrm{c}}$ & $81.48^{\mathrm{c}}$ \\
$25 \%$ & 7.69 & 9.11 & 13.89 & $21.74^{\mathrm{d}}$ & $28.96^{\mathrm{d}}$ & $61.59^{\mathrm{d}}$ & $84.51^{\mathrm{c}}$ \\
$50 \%$ & 7.44 & 8.70 & 13.05 & $18.46^{\mathrm{c}}$ & $25.62^{\mathrm{c}}$ & $50.81^{\mathrm{b}}$ & $67.59^{\mathrm{b}}$ \\
$75 \%$ & 7.84 & 9.17 & 12.33 & $16.18^{\mathrm{a}}$ & $20.81^{\mathrm{a}}$ & $35.74^{\mathrm{a}}$ & $44.29^{\mathrm{a}}$ \\
\hline Daerah Asal Bibit & & & & & & & \\
Sukabumi & 6.96 & 8.30 & 12.70 & 18.36 & 24.58 & 52.78 & 72.11 \\
Cianjur & 7.51 & 8.77 & 13.31 & 18.97 & 25.72 & 52.69 & 69.08 \\
Bogor & 7.66 & 10.97 & 13.03 & 18.36 & 24.69 & 49.14 & 67.22 \\
\hline
\end{tabular}

Keterangan: Nilai rata-rata pada kolom yang sama diikuti huruf yang sama tidak berbeda nyata menurut uji BNT pada taraf $5 \%$

Jumlah daun kenikir dipengaruhi oleh naungan (3 - 8 MST), dan asal daerah (pada umur 3,6 dan 8 MST) tetapi tidak terdapat interaksi antar keduanya. Pada umur 7 - 8 MST jumlah daun pada tingkat naungan $0 \%$ nyata lebih banyak dibanding tingkat naungan lainnya, walaupun pada umur $4-6$ MST jumlah daun kenikir yang dinaungi $25 \%$ nyata lebih besar dibandingkan dengan yang dinaungi 0\%, 50\% dan 75\% (Tabel 2).

Tabel 2 Jumlah daun tanaman kenikir pada umur 2-8 MST

\begin{tabular}{|c|c|c|c|c|c|c|c|}
\hline \multirow{2}{*}{ Perlakuan } & \multicolumn{7}{|c|}{ Jumlah daun (helai) } \\
\hline & $2 \mathrm{MST}$ & $3 \mathrm{MST}$ & 4 MST & $5 \mathrm{MST}$ & 6 MST & $7 \mathrm{MST}$ & $8 \mathrm{MST}$ \\
\hline \multicolumn{8}{|l|}{ Tingkat Naungan } \\
\hline $0 \%$ & & $6.51^{\mathrm{d}}$ & $8.66^{\mathrm{b}}$ & $13.96^{c}$ & $43.48^{c}$ & $90.29^{d}$ & $104.48^{d}$ \\
\hline $25 \%$ & & $6.48^{c}$ & $9.00^{\mathrm{d}}$ & $14.07^{\mathrm{d}}$ & $46.37^{\mathrm{d}}$ & $88.96^{c}$ & $97.55^{c}$ \\
\hline $50 \%$ & & $6.11^{b}$ & $8.74^{c}$ & $12.55^{\mathrm{b}}$ & $33.55^{b}$ & $72.37^{b}$ & $81.62^{b}$ \\
\hline $75 \%$ & & $5.55^{\mathrm{a}}$ & $7.25^{\mathrm{a}}$ & $10.22^{\mathrm{a}}$ & $12.88^{\mathrm{a}}$ & $17.55^{\mathrm{a}}$ & $20.29^{a}$ \\
\hline \multicolumn{8}{|l|}{ Daerah Asal Bibit } \\
\hline Sukabumi & & $6.88^{\mathrm{b}}$ & $8.88^{b}$ & $13.66^{b}$ & $43.58^{b}$ & $73.80^{b}$ & $82.55^{\mathrm{b}}$ \\
\hline Cianjur & & $5.94^{\mathrm{a}}$ & $8.52^{b}$ & $12.66^{\mathrm{b}}$ & $32.41^{b}$ & $65.36^{\mathrm{b}}$ & $74.55^{b}$ \\
\hline Bogor & & $5.66^{\mathrm{a}}$ & $7.83^{\mathrm{a}}$ & $11.77^{\mathrm{a}}$ & $26.22^{\mathrm{a}}$ & $62.72^{\mathrm{a}}$ & $70.91^{\mathrm{a}}$ \\
\hline
\end{tabular}

Keterangan: Nilai rata-rata pada kolom yang sama diikuti huruf yang sama tidak berbeda nyata menurut uji BNT pada taraf $5 \%$ 
Panjang daun kenikir dipengaruhi oleh asal daerah (pada umur 5, 7 dan 8 MST), naungan (pada umur 7 MST), dan interaksi keduanya (7 MST). Pada umur 5 dan 8 MST panjang daun tanaman kenikir yang diberi tingkat naungan $75 \%$ nyata lebih rendah dibandingkan dengan yang lainnya (Tabel 3 ).

Tabel 3 Panjang daun kenikir pada umur 4 - 8 MST

\begin{tabular}{|c|c|c|c|c|c|}
\hline \multirow{2}{*}{ Perlakuan } & \multicolumn{5}{|c|}{ Panjang daun $(\mathrm{cm})$} \\
\hline & $4 \mathrm{MST}$ & $5 \mathrm{MST}$ & $6 \mathrm{MST}$ & $7 \mathrm{MST}$ & $8 \mathrm{MST}$ \\
\hline \multicolumn{6}{|l|}{ Tingkat Naungan } \\
\hline $0 \%$ & 9.70 & $11.88^{b}$ & 14.44 & $16.70^{\mathrm{a}}$ & $18.96^{b}$ \\
\hline $25 \%$ & 10.22 & $13.59^{b}$ & 16.56 & $20.29^{b}$ & $24.22^{b}$ \\
\hline $50 \%$ & 10.81 & $13.48^{\mathrm{b}}$ & 16.41 & $19.51^{\mathrm{b}}$ & $22.81^{b}$ \\
\hline $75 \%$ & 9.04 & $4.40^{\mathrm{a}}$ & 4.41 & $20.66^{\mathrm{b}}$ & $4.40^{\mathrm{a}}$ \\
\hline \multicolumn{6}{|l|}{ Daerah Asal Bibit } \\
\hline Sukabumi & 9.89 & 0.72 & 0.72 & $17.19^{\mathrm{a}}$ & 0.72 \\
\hline Cianjur & 9.92 & 1.31 & 1.31 & $20.69^{b}$ & 1.31 \\
\hline Bogor & 10.03 & 1.28 & 1.28 & $20.00^{b}$ & 1.28 \\
\hline
\end{tabular}

Keterangan: Nilai rata-rata pada kolom yang sama diikuti huruf yang sama tidak berbeda nyata menurut uji BNT pada taraf $5 \%$

Pada tingkat naungan $0 \%$, panjang daun kenikir asal Cianjur nyata lebih besar dibandingkan asal Sukabumi, tetapi tidak berbeda nyata dengan tanaman asal Bogor. Pada tingkat naungan 25\%, panjang daun kenikir asal Cianjur nyata lebih besar dibandingkan dengan asal Bogor, tetapi tidak berbeda nyata dengan asal Sukabumi. Pada tingkat naungan 50\%, panjang daun kenikir tidak berbeda antar daerah asal bibit. Pada tingkat naungan $75 \%$, panjang daun kenikir asal Cianjur nyata lebih besar dibandingkan asal Bogor dan Sukabumi.

Tabel 4 Panjang daun kenikir pada umur 7 MST pada kombinasi tingkat naungan dan daerah asal

\begin{tabular}{lcccc}
\hline \multirow{2}{*}{ Perlakuan } & \multicolumn{3}{c}{ Tingkat Naungan } \\
\cline { 2 - 4 } & $0 \%$ & $25 \%$ & $50 \%$ & $75 \%$ \\
\hline Asal Daerah Bibit & & & \\
Sukabumi & $42.33^{\mathrm{a}}$ & $61^{\mathrm{cd}}$ & $60.66^{\mathrm{c}}$ & $42.33^{\mathrm{a}}$ \\
Cianjur & $56.66^{\mathrm{bc}}$ & $61.33^{\mathrm{d}}$ & $54.33^{\mathrm{bc}}$ & $76.00^{\mathrm{e}}$ \\
Bogor & $51.33^{\mathrm{ab}}$ & $60.33^{\mathrm{c}}$ & $60.66^{\mathrm{c}}$ & $67.66^{\mathrm{d}}$ \\
\hline
\end{tabular}

Keterangan: Nilai rata-rata pada kolom yang sama diikuti huruf yang sama tidak berbeda nyata menurut uji BNT pada taraf 5\%

Lebar daun kenikir dipengaruhi oleh tingkat naungan (pada umur 8 MST), tetapi tidak dipengaruhi oleh daerah asal dan interaksi keduanya. Pada umur 8 MST lebar daun tanaman kenikir dengan perlakuan naungan $75 \%$ nyata lebih tinggi dibanding tingkat naungan lainnya (Tabel 5). 
Tabel 5 Lebar daun kenikir pada umur 4-8 MST

\begin{tabular}{cccccc}
\hline \multirow{2}{*}{ Perlakuan } & \multicolumn{5}{c}{ Lebar daun kenikir (cm) } \\
\cline { 2 - 6 } & 4 MST & 5 MST & 6 MST & 7 MST & 8 MST \\
\hline Tingkat Naungan & & & & & \\
$0 \%$ & 7.56 & 10.22 & 12.81 & 15.04 & $17.07^{\mathrm{a}}$ \\
$25 \%$ & 7.48 & 10.04 & 13.19 & 17.04 & $20.74^{\mathrm{c}}$ \\
$50 \%$ & 9.22 & 11.96 & 14.48 & 17.30 & $19.74^{\mathrm{b}}$ \\
$75 \%$ & 6.78 & 10.41 & 14.30 & 17.04 & $21.62^{\mathrm{d}}$ \\
\hline Daerah Asal Bibit & & & & \\
Sukabumi & 7.53 & 9.67 & 12.42 & 14.86 & 17.00 \\
Cianjur & 7.58 & 11.44 & 14.61 & 17.56 & 21.97 \\
Bogor & 8.17 & 10.86 & 14.06 & 17.39 & 20.42 \\
\hline
\end{tabular}

Keterangan: Nilai rata-rata pada kolom yang sama diikuti huruf yang sama tidak berbeda nyata menurut uji BNT pada taraf $5 \%$

Jumlah tunas dipengaruhi oleh tingkat naungan dan asal daerah (3 MST), tetapi tidak terdapat interaksi antar keduanya. Pada umur 3 MST jumlah tunas tanaman kenikir dengan perlakuan tanpa naungan nyata lebih banyak dibanding dengan yang diberi naungan. Pada umur 3 MST jumlah tunas tanaman kenikir asal Sukabumi nyata lebih banyak dibandingkan dengan daerah lainnya (Tabel $6)$.

Tabel 6. Banyaknya tunas tanaman kenikir pada umur 3-6 MST

\begin{tabular}{lcccc}
\hline \multirow{2}{*}{ Perlakuan } & \multicolumn{4}{c}{ Banyaknya tunas (buah) } \\
\cline { 2 - 5 } & $3 \mathrm{MST}$ & $4 \mathrm{MST}$ & $5 \mathrm{MST}$ & $6 \mathrm{MST}$ \\
\hline Tingkat Naungan & & & & \\
$0 \%$ & $7.18^{\mathrm{d}}$ & 5.63 & 3.22 & 2.44 \\
$25 \%$ & $6.92^{\mathrm{c}}$ & 3.33 & 2.30 & 2.02 \\
$50 \%$ & $5.33^{\mathrm{b}}$ & 3.70 & 2.70 & 2.11 \\
$75 \%$ & $2.33^{\mathrm{a}}$ & 3.22 & 2.81 & 2.36 \\
\hline Daerah Asal Bibit & & & & \\
Sukabumi & $6.13^{\mathrm{b}}$ & 0.33 & 2.75 & 2.17 \\
Cianjur & $5.83^{\mathrm{a}}$ & 0.28 & 2.92 & 2.40 \\
Bogor & $4.36^{\mathrm{a}}$ & 0.25 & 2.61 & 2.12 \\
\hline Keterangan: Nilai rata-rata pada kolom yang sama diikuti huruf yang sama tidak berbeda nyata \\
\multicolumn{2}{l}{ menurut uji BNT pada taraf 5\% } & &
\end{tabular}

Diameter batang tanamankenikir dipengaruhi oleh naungan (pada umur4-8 MST),tetapi tidak dipengaruhi oleh daerah asal bibit dan interaksi keduanya. Pada umur 4 -8 MST diameter batang tanaman kenikir dengan tingkat naungan $0 \%$ nyata lebih besar dibandingkan dengan tingkat naungan lainnya.Penambahan tingkat naungan nyata menurunkan diameter batang kenikir ( Tabel 7). 
Tabel 6 Diameter batang tanaman kenikir pada umur 4-8 MST

\begin{tabular}{lccccc}
\hline \multirow{2}{*}{ Perlakuan } & \multicolumn{5}{c}{ Diameter batang $(\mathrm{mm})$} \\
\cline { 2 - 6 } & $4 \mathrm{MST}$ & $5 \mathrm{MST}$ & $6 \mathrm{MST}$ & $7 \mathrm{MST}$ & $8 \mathrm{MST}$ \\
\hline Tingkat Naungan & & & & & \\
$0 \%$ & $9.238^{\mathrm{c}}$ & $12.95^{\mathrm{c}}$ & $16.12^{\mathrm{d}}$ & $21.24^{\mathrm{d}}$ & $27.32^{\mathrm{d}}$ \\
$25 \%$ & $11.52^{\mathrm{d}}$ & $13.72^{\mathrm{d}}$ & $14.89^{\mathrm{c}}$ & $19.78^{\mathrm{c}}$ & $25.76^{\mathrm{c}}$ \\
$50 \%$ & $8.88^{\mathrm{b}}$ & $11.29^{\mathrm{b}}$ & $12.26^{\mathrm{b}}$ & $16.13^{\mathrm{b}}$ & $21.60^{\mathrm{b}}$ \\
$75 \%$ & $3.70^{\mathrm{a}}$ & $5.20^{\mathrm{a}}$ & $6.03^{\mathrm{a}}$ & $8.02^{\mathrm{a}}$ & $10.71^{\mathrm{a}}$ \\
\hline Daerah Asal Bibit & & & & & \\
Sukabumi & 8.10 & 10.47 & 11.85 & 15.32 & 19.96 \\
Cianjur & 8.43 & 10.86 & 12.56 & 16.69 & 21.77 \\
Bogor & 8.48 & 11.05 & 12.58 & 16.88 & 22.31 \\
\hline Keterangan: Nilai rata-rata pada kolom yang sama diikuti huruf yang sama tidak berbeda nyata menurut uji \\
\multicolumn{5}{l}{ BNT pada taraf 5\% }
\end{tabular}

\section{Kandungan Klorofil}

Kandungan klorofil a dan klorofil b dipengaruhi daerah asal bibit tetapi tidak dipengaruhi tingkat naungan dan tidak terjadi interaksi keduanya. Kandungan klorofil a dan Klorofil b kenikir asal Cianjur nyata lebih tinggi dibandingkan dengan Sukabumi dan Bogor (Tabel 8).

Tabel 7 Klorofil tanaman kenikir

\begin{tabular}{lccc} 
Perlakuan & $\begin{array}{c}\text { klorofil a } \\
(\mathrm{mg} / \mathrm{g})\end{array}$ & $\begin{array}{c}\text { klorofil b } \\
(\mathrm{mg} / \mathrm{g})\end{array}$ & $\begin{array}{c}\text { Total klorofil } \\
(\mathrm{mg} / \mathrm{g})\end{array}$ \\
\hline $\begin{array}{c}\text { Tingkat Naungan } \\
0 \%\end{array}$ & 2.24 & & \\
$25 \%$ & 2.74 & 1.04 & 3.29 \\
$50 \%$ & 2.87 & 1.32 & 4.05 \\
$75 \%$ & 2.81 & 1.43 & 4.31 \\
$\quad 1.50$ & 4.31 \\
\hline Daerah Asal Bibit & & & \\
Sukabumi & $2.73^{\mathrm{a}}$ & $1.35^{\mathrm{a}}$ & $4.09^{\mathrm{a}}$ \\
Cianjur & $2.80^{\mathrm{b}}$ & $1.39^{\mathrm{b}}$ & $4.19^{\mathrm{b}}$ \\
Bogor & $2.45^{\mathrm{a}}$ & $1.22^{\mathrm{a}}$ & $3.67^{\mathrm{a}}$ \\
\hline
\end{tabular}

Keterangan: Nilai rata-rata pada kolom yang sama diikuti huruf yang sama tidak berbeda nyata menurut uji BNT pada taraf 5\%

Hasil panen dipengaruhi naungan akan tetapi tidak dipengaruhi asal daerah bibit dan interaksi keduanya. Hasil panen dengan tingkat naungan $75 \%$ nyata lebih rendah dibanding tingkat naungan lainnya. Peningkatan intensitas naungan, nyata menurunkan hasil panen kenikir (Tabel 9).

Tabel 8 Bobot basah dan bobot kering panen kenikir

\begin{tabular}{|c|c|c|c|c|c|c|c|c|}
\hline \multirow{2}{*}{ Perlakuan } & \multicolumn{3}{|c|}{ Bobot basah } & \multirow{2}{*}{ total } & \multicolumn{3}{|c|}{ Bobot kering } & \multirow{2}{*}{ Total } \\
\hline & Panaen 1 & panen 2 & Panen3 & & Panaen 1 & panen 2 & panen 3 & \\
\hline \multicolumn{9}{|c|}{ Tingkat Naungan } \\
\hline $0 \%$ & $48.25 \mathrm{c}$ & $34.81^{\mathrm{c}}$ & $33.40^{c}$ & $116.47^{\mathrm{c}}$ & $8.12^{\mathrm{c}}$ & 7.68 & $5.27^{\mathrm{d}}$ & $21.04^{\mathrm{c}}$ \\
\hline $25 \%$ & $41.92 \mathrm{c}$ & $34.95^{\mathrm{d}}$ & $39.80^{\mathrm{d}}$ & $116.68^{\mathrm{c}}$ & $7.05^{c}$ & 6.90 & $5.74^{\mathrm{c}}$ & $19.24^{\mathrm{c}}$ \\
\hline $50 \%$ & $29.37 \mathrm{~b}$ & $23.45^{b}$ & $25.44^{b}$ & $78.27^{b}$ & $4.73^{b}$ & 4.83 & $3.98^{b}$ & $13.54^{\mathrm{b}}$ \\
\hline $75 \%$ & $5.37 \mathrm{a}$ & $5.55^{\mathrm{a}}$ & $4.87^{\mathrm{a}}$ & $15.72^{\mathrm{a}}$ & $0.71^{\mathrm{a}}$ & 0.79 & $0.56^{\mathrm{a}}$ & $1.03^{\mathrm{a}}$ \\
\hline
\end{tabular}




\begin{tabular}{|c|c|c|c|c|c|c|c|c|}
\hline \multirow{2}{*}{ Perlakuan } & \multicolumn{3}{|c|}{ Bobot basah } & \multirow{2}{*}{ total } & \multicolumn{3}{|c|}{ Bobot kering } & \multirow{2}{*}{ Total } \\
\hline & Panaen 1 & panen 2 & Panen3 & & Panaen 1 & panen 2 & panen3 & \\
\hline \multicolumn{9}{|c|}{ Daerah Asal Bibit } \\
\hline Sukabumi (K1) & 33.19 & 26.12 & 27.35 & 86.66 & 5.41 & 5.61 & 4.12 & 0.16 \\
\hline Cianjur (K2) & 27.61 & 22.81 & 23.26 & 73.62 & 4.73 & 4.29 & 3.53 & 0.16 \\
\hline Bogor (K3) & 32.89 & 25.16 & 27.04 & 85.09 & 5.34 & 5.24 & 4.03 & 0.16 \\
\hline
\end{tabular}

Keterangan: Nilai rata-rata pada kolom yang sama diikuti huruf yang sama tidak berbeda nyata menurut uji BNT pada taraf $5 \%$

\section{Pembahasan}

Tanaman kenikir yang mendapat naungan sebesar $50 \%$ dan $75 \%$ menunjukkan tinggi tanaman, panjang daun, diameter batang, bobot basah dan kering panen lebih rendah, tetapi lebar daun lebih besar dibandingkan dengan yang ditanam pada tingkat naungan $0 \%$ dan $25 \%$. Berkurangnya intensitas cahaya mengakibatkan terjadinya perubahan iklim mikro seperti suhu udara dan kelembaban udara di sekitar daerah pertanaman (Widiastoety dan Bahar 1995). Suhu udara menentukan laju difusi zat cair di dalam tanaman, apabila suhu udara turun maka kekentalan air menjadi naik sehingga menyebabkan proses fotosintesis menurun (Sudaryono 2001). Jumlah daun kenikir asal Sukabumi dan Cianjur lebih banyak dibandingkan dengan asal Bogor, kandungan klorofil daun kenikir asal Cianjur lebih banyak dibandingkan dengan asal Sukabumi dan Bogor, tetapi hasil panen ketiga aksesi tidak berbeda nyata.

Jumlah tunas pada umur 3 MST dengan tingkat naungan 0\% lebih tinggi karena cahaya matahari yang diterima lebih banyak dibandingkan perlakuan lainnya, sehingga proses fotosintesis akan berjalan maksimal. Hal ini memicu perkembangan tanaman dan memicu munculnya tunas-tunas baru.

Tanaman yang tumbuh pada intensitas cahaya yang rendah (naungan $75 \%$ ), menunjukkan ukuran lebar daun lebih besar karena tanaman yang ternaungi akan memperluas permukaan daun supaya mendapatkan cahaya yang optimal. Daun yang ternaungi lebih hijau (Lakitan 2001), sedangkan daun terkena sinar matahari langsung berwarna hijau keunguan. Penambahan tingkat naungan diiringi oleh peningkatan jumlah klorofil total, walaupun dalam penelitian tidak berbeda nyata. Hal ini sesuai dengan yang dinyatakan oleh Salisbury dan Ross (1995), bahwa berdasarkan bobot daun pada kondisi ternaungi umumnya mempunyai klorofil yang lebih banyak. Kandungan klorofil yang lebih banyak pada tanaman di bawah naungan berfungsi untuk memaksimalkan penyerapan cahaya pada kondisi cahaya yang rendah.

Bobot basah dan kering tanaman kenikir dengan tingkat naungan $25 \%$ nyata lebih tinggi dibandingkan dengan tingkat naungan $50 \%$ dan $75 \%$, tetapi tidak berbeda dengan tanpa naungan. Hal ini menunjukkan tanaman kenikir masih toleran sampai tingkat naungan $25 \%$.

\section{KESIMPULAN}

Tingkat naungan $50 \%$ dan $75 \%$ nyata menurunkan tinggi tanaman, panjang daun, diameter batang, bobot basah dan kering panen, tetapi meningkatkan lebar daun kenikir. Jumlah daun kenikir asal Sukabumi dan Cianjur lebih banyak dibandingkan dengan asal Bogor, kandungan klorofil daun kenikir asal Cianjur lebih banyak dibandingkan dengan asal Sukabumi dan Bogor, tetapi hasil panen ketiga aksesi tidak berbeda nyata.

\section{DAFTAR PUSTAKA}

Archita A. 2005. Pengaruh Intensitas Cahaya Rendah Terhadap Keragaan Sifat Agronomis Tanaman Temu-temuan (Curcuma spp.).[Skripsi]. Departemen Budidaya Pertanian. Fakultas Pertanian, Institut Pertanian Bogor. Bogor.

AVRDC. 2008. Collection and conservation of indigenous germplasm to enhance and 
maintain livelihoods in ASEAN. (http://www.avrdc.org).[22 Juli 2016].

Baihaki A. 2003.Aspek sosial ekonom dalam pemanfaatan dan pelestarian keanekaragaman hayati Jawa Barat. J. Ekologi dan Biodiversitas Tropika.

Lestari MA. 2008. Pengaruh Pemupukan terhadap Pertumbuhan dan Produktivitas Beberapa Sayuran Indigenous.[Skripsi]. Bogor: Program StudiHortikultura. Fakultas Pertanian, Institut Pertanian Bogor.

Lotulung PDN, Minarti, Kardono LBS. 2001. Penapisan Aktivitas Antibakteri, Antioksidan dan Toksisitas terhadap Larva Udang Artemia salina Ekstrak Tumbuhan Asteraceae, Abstrak, Pusat Penelitian Kimia LIPI

Rafat A, Philip K, Muniandy S. 2011. Antioxidant properties of indigenous raw and fermented salad plants. Int. J. Food Prop. 14:599-608.

Salisbury FB, Roos CW. 1995. Fisiologi Tumbuhan Jilid 3. Diterjemahkan oleh
DR Lukman dan Sumarjono. Bandung :Penerbit ITB.

Setyowati N, 2011. Pengaruh Intensitas Cahaya dan Media Tanam Terhadap Pertumbuhan Bibit Rosella.. J. Agrivigor, 10 (2):218-227.

Sudaryono. 2011. Pengaruh bahan pengkondisi tanah terhadap iklim mikro pada lahan berpasir. Jurnal Teknologi Lingkungan. 2(2): 175-184.

SetyaningrumHDC. Saparinto. 2011. Panen Sayur Secara Rutin di Lahan Sempit. Jakarta: Penebar Swadaya

Vorster IHJ, van Rensburg WSJ, van Zijl JJB, Venter SL. 2007. The importance of traditional leavy vegetables in South Africa. African J, Food Agriculture Nutrition and Development. 7(4):2-13.

Widiastoety D, Bahar FA. 1995. Pengaruh intensitas cahaya terhadap pertumbuhan anggrek dendrobium. [Jurnal]Horti. 5 (4):72-7 